\title{
Technical and radiological characterisation of fly ash and bottom ash from thermal power plant
}

\author{
Emilija Fidanchevski ${ }^{1}$ (1) $\cdot$ Biljana Angjusheva ${ }^{1} \cdot$ Vojo Jovanov $^{1} \cdot$ Pece Murtanovski $^{2} \cdot$ Ljubica Vladiceska $^{3}$. \\ Nikolina Stamatovska Aluloska ${ }^{3} \cdot$ Jelena Krneta Nikolic ${ }^{4} \cdot$ Andrej Ipavec $^{5} \cdot$ Katarina Šter $^{6} \cdot$ Maruša Mrak $^{6}$. \\ Sabina Dolenec ${ }^{6}$
}

Received: 16 April 2021 / Accepted: 30 August 2021 / Published online: 18 September 2021

(c) The Author(s) 2021

\begin{abstract}
Huge quantities of fly ash and bottom ash are generated from thermal power plants and it presents great concern for country, mainly due to the environmental effects. In this study, fly ashes and bottom ash were characterized from technical and radiological aspects. Health effect due to the activity of radionuclides ${ }^{226} \mathrm{Ra},{ }^{232} \mathrm{Th}$ and ${ }^{40} \mathrm{~K}$ was estimated via radium equivalent activity (Raeq), external hazards index $\left(\mathrm{H}_{\mathrm{ex}}\right)$, the external absorbed dose rate (D) and annual effective dose rate (EDR). The specific surface area $\left(40.25 \mathrm{~m}^{2 \mathrm{~g}-1}\right)$, particle density $\left(1.88 \mathrm{~g} \mathrm{~cm}^{-3}\right)$ and LOI $(23.49 \%)$ were typical for bottom ash. Siliceous fly ash contained $32 \%$ reactive silica. The annual effective dose rate for all ashes is $\leq 0.2 \mathrm{mSv} \mathrm{y}^{-1}$. Both, fly ash and bottom ash present potential secondary raw materials to be used for building purposes as result of their technological and radiological assessment.
\end{abstract}

Keywords Fly ash $\cdot$ Bottom ash $\cdot$ Gamma spectrometry $\cdot$ Building materials

\section{Introduction}

Fly ash (FA) and bottom ash (BA) are the major industrial residues (waste/ by-products) formed with the production of electricity in thermal power plants. FA presents fine particulate residue resulting from the combustion of coal which is captured from fly gas and collected by electrostatic

Emilija Fidanchevski

emilijaf@tmf.ukim.edu.mk

1 Faculty of Technology and Metallurgy, Ss. Cyril and Methodius University in Skopje, Ruger Boskovic 16, 1000 Skopje, Republic of North Macedonia

2 Elektrani na Severna Makedonija, 11 Oktomvri 9, 1000 Skopje, Republic of North Macedonia

3 Cementarnica “USJE”AD Titan Group, Boris Trajkovski 94, 1000 Skopje, Republic of North Macedonia

4 Radiation and Environment Protection Department, Vinca Institute for Nuclear Science, National Institute of the Republic of Serbia, University of Belgrade, Belgrade, Serbia

5 Salonit Anhovo d.d, Anhovo 1, 5210 Deskle, Slovenia

6 Slovenian National Building and Civil Engineering Institute, Dimičeva ulica 12, 1000 Ljubljana, Slovenia precipitator. BA is heavier and harder to be carried out with fly gas and it is collected at the bottom of the boiler. The particles of BA are much coarser, angular and large sized (in range from sand to gravel size) with rough surface texture and gray color due to the presence of unburn carbon. BA possess high permeability, strength and compressibility which properties make BA promising material for civil engineering applications. Chemical composition of BA is similar to FA, (mainly composed of $\mathrm{SiO}_{2}, \mathrm{Al}_{2} \mathrm{O}_{3}, \mathrm{Fe}_{2} \mathrm{O}_{3}, \mathrm{CaO}$ and small amounts of magnesia, titania, etc.), but with greater content of unburned carbon. Fly ash particles are spherical and alkaline in nature [1-3].

The management of both ashes remains the global environmental problem. Significant amounts of ashes are already used in range of applications, but still there is need to address the potential reuse of ashes. Recent literature reports the application of FA in construction: as raw material in Portland cement clinker [4] and belite-sulfoaluminate clinkers [5], as pozzolanic addition in cement [6], concrete $[6,7]$, light weight aggregate [6], bricks [8], glass-ceramics [9] etc. Also, other uses are being developed, like adsorbents [6, 10], zeolites [11], macro and micro nutrients in agriculture [10]. Nowadays its potential utilization due to the new technologies is much wider in the sense of its 
green transformation. For instance, fly ash can be used as a source of carbon for the synthesis of nanomaterials (carbon nanotubes), aerogels, geopolymers and rare earth elements [12]. Bottom ash showed better capability to be used for geotechnical construction like in roadways, embankments and fill material [13], as constituent in belite-sulfoaluminate clinkers [14] and as micro filer in concrete [15], but also as constituent in Portland cement [16] glass-ceramics [17], ceramics [18], etc. According to European Coal Combustion Products Association [19] most of the coal combustion products (CCPs) produced are used in the construction industry, in civil engineering and as construction materials in underground mining (52.4 wt.\%) or for restoration of open cast mines, quarries and pits (35.9 wt.\%), fly ash (FA) in blended cements $(11 \%)$ and cement raw material $(26 \%)$ of 21 million tons and bottom ash (BA) in cements (10\%) of 2.6 million tons.

The composition, morphology and size of particles, the nature of crystalline phases and glasses, unburned carbon, trace and heavy elements vary in fly ash and bottom ash, but the above mentioned variations influence on the behavior of ashes in their applications. On the other hand, coal ashes (fly ash and bottom ash) as industrial residues (waste and/ or by-products) contain enriched concentrations of natural radionuclides considered as naturally occurring radioactive materials (NORM). According to the Council Directive 2013/59/EUROATOM, 2013, Article 75 [20], the referent level for indoor external exposure due to the gamma radiation emitted by building materials is $1 \mathrm{mSv} \mathrm{y}^{-1}$. Also, the directive defines the activity concentration index for gamma radiation emitted by building materials-I as a conservative screening tool to identify building materials that may be of concern from a radiation protection point of view. NORM used in the final building material has to be assessed from a radiological point of view before it is used in standard practice.

This study presents part of the results of RIS ALiCE registry [21] developed for Al-containing secondary mineral residues (industrial and mine wastes/ by-products) as a base for increased production of low $\mathrm{CO}_{2}$ mineral binders, based on belite-sulfoaluminmate clinkers (BCSA) in ESEE region [22]. This work aimed to determine the technical and radiological characterization of the fly ash (fresh and landfilled/ historical) and bottom ash from the thermal power plant REK Bitola, Republic of North Macedonia and to foresee the potential for their utilization. Thermal power plant REK Bitola is the main producer of energy in the Republic of North Macedonia participating with more than $80 \%$ of the total electricity production [23]. Annually, 1.5 million tons of fly ash are produced and only 120000 tones are utilized as blended in cement [24]. Large quantities of fly ash and bottom ash remain on the surrounding of the thermal plant and the potential sustainable solutions are needed.

\section{Experimental}

\section{Materials}

The materials used in this research were obtained from the largest thermal power plant (REK Bitola) from Republic of North Macedonia. Three ashes were investigated: fresh fly ash (FA) sampled from electro filter, landfilled/historical fly ash (LFA) sampled from the open land field and bottom ash (BA) sampled from the bottom of the reactor.

\section{Methods}

\section{Physical characterization}

Particle size distribution (PSD) of the fly ash and bottom ash was dry measured by a laser scattering particle size distribution analyzer (HelosH4087 \& RODOS). Ashes passed through the $200 \mu \mathrm{m}$ sieve prior to the PSD analyses [25].

Moisture content was calculated by the relation: \% $\mathrm{mc}_{\mathrm{wb}}=\left(\mathrm{m}_{\mathrm{w}}-\mathrm{m}_{\mathrm{d}} / \mathrm{m}_{\mathrm{w}}\right) \times 100$, where $\mathrm{mc}_{\mathrm{wb}}$ is expressed on a wet basis (where: $m_{w}$ is the mass of the wet fly ash and $m_{d}$ is the mass of dry fly ash). The particle density of ashes was determined by the pycnometer method [26] and bulk density according to JUSB.C8.023 standard [27].

The morphology of the ashes was investigated by scanning electron microscope (JEOL JSM 5500LV). The specific surface area (SSA) of the ashes was determined by BET method (Micromeritics ASAP-2020), by nitrogen adsorption measurements at $77 \mathrm{~K}$.

\section{Chemical and mineralogical composition}

The chemical composition of fly ashes and bottom ash was carried out on fuse bead samples by $\mathrm{x}$-ray fluorescence spectroscopy (ARL 9900 instrument). Reactive silicon dioxide $\left(\mathrm{SiO}_{2}\right)$ only at FA and loss of ignition (LOI) were determined according to the EN196-2 standard [28].

Trace elements (TE) and rare earth elements (REE) were determined by ICP-OES (Perkin Elmer Avio200 ICP-OES) instrument with S10 autosampler, MiraMIST nebulizer, glass baffled cyclonic spray chamber and lutetium as the internal standard. Sample preparation include grinding to under $1 \mathrm{~mm}$ and fusion with lithium metaborate $(0.5 \mathrm{~g}$ sample $+1.16 \mathrm{~g}$ lithium metaborate $+0.05 \mathrm{~g} \mathrm{NH}_{4} \mathrm{NO}_{3}$ ) at $1000{ }^{\circ} \mathrm{C}(1 \mathrm{~h})$ in platinum crucible [29]. AMA 254 Advanced Mercury Analyzer was used for determination of mercury.

The mineralogical composition of ashes was determined by an X-ray diffractometer (PANalytical Empyrean). The internal wavelengths used were from copper anodes $(\lambda \mathrm{CuK} \alpha 1=1.54 \AA, \lambda \mathrm{CuK} \alpha 2=1.54 \AA, \lambda \mathrm{CuK} \beta 1=1.39 \AA)$ 
with a reflection transmission spinner configuration. Samples were ground in an agate mortar to a particle size below $0.063 \mathrm{~mm}$. The ground powder was manually back-loaded into a circular sample holder (diameter $27 \mathrm{~mm}$ ), data for each sample were collected from $4^{\circ}$ to $70^{\circ}(2 \theta)$. The X-ray tube worked at $45 \mathrm{kV}$ and $40 \mathrm{~mA}$ and the samples were rotated during data collection at a revolution time of $2 \mathrm{~s}$. Amount of amorphous phase and mineral phases were estimated by Rietveld refinement with the external standard method (pure corundum, $\mathrm{Al}_{2} \mathrm{O}_{3}$; NIST 6769) and PANalyticalX'Pert High Score Plus diffraction software, using the structures for the phases from ICDD PDF 4+2016 RDB powder diffraction files.

\section{Radiological characterization}

Gamma-ray spectrometry Gamma spectrometry was employed for measuring the activity concentration of radionuclides in coal ashes. The ash samples were placed in PVC cylindrical containers six weeks prior to the measurements in order to reach the radioactive equilibrium.

Radiological analysis was performed according to the [30] employing a coaxial semiconductor high purity germanium (HPGe) detector (Canberra GC5019 with 50\% relative efficiency and $1.8 \mathrm{keV}$ resolution for ${ }^{60} \mathrm{Co}$ line at $1332 \mathrm{keV}$ ) associated with a standard high voltage supply and electronics units. Based on the obtained results for ${ }^{226} \mathrm{Ra},{ }^{232} \mathrm{Th}$ and ${ }^{40} \mathrm{~K}$ activity concentration of ashes, the I-index was determined (considered as a screening tool for the radiological behaviour of ashes) and dose assessment was performed.

Activity concentration index (I-index) The index I was calculated, according to Eq. (1) [20].

$\mathrm{I}=\mathrm{C}_{226 \mathrm{Ra}} / 300+\mathrm{C}_{232 \mathrm{Th}} / 200+\mathrm{C}_{40 \mathrm{~K}} / 3000$

where $\mathrm{C}_{226 \mathrm{Ra}}, \mathrm{C}_{232 \mathrm{Th}}$ and $\mathrm{C}_{40 \mathrm{~K}}$ are activity concentrations in $\mathrm{Bq} \mathrm{kg}{ }^{-1}$ in the measured samples.

Dose assessment \& radium equivalent activity \& The external hazard index Radium equivalent activity, $R a_{e q}(\mathrm{~Bq}$ $\left.\mathrm{kg}^{-1}\right)$, the external hazard index, $H_{e x}\left(\mathrm{~Bq} \mathrm{~kg}^{-1}\right)$, total external absorbed gamma dose rate $\mathrm{D}\left(\mathrm{nGy} \mathrm{h}^{-1}\right)$ and annual effective dose rate $E D R\left(\mathrm{mSv} \mathrm{y}^{-1}\right)$ were calculated in order to estimate the potential health effect of the ashes due to the exposure of the public to natural radioactivity.

The radium equivalent activity, $R a_{e q}$, as a tool to limit the exposure to radiation, was calculated according to Eq. (2). It should be lower or equal to $370 \mathrm{~Bq} \mathrm{~kg}^{-1}$ in order to limit the gamma dose from building materials to $1 \mu \mathrm{Sv}^{-1}$ [31].

$R a_{e q}=C_{R a}+1.43 C_{T h}+0.077 C_{k}$
The external hazard index, $H_{e x}$, was calculated according to Eq. (3) and it reflects the external radiation hazard due to the emitted gamma radiation.

$H_{e x}=\left(C_{R a} / 370\right)+\left(C_{T h} / 259\right)+\left(C_{K} / 4180\right)$

The external terrestrial gamma radiation absorbed dose rate, $\mathrm{D}$, in the air at a height of $1 \mathrm{~m}$ above ground level due to the presence of radionuclides ${ }^{226} \mathrm{Ra},{ }^{232} \mathrm{Th}$ and ${ }^{40} \mathrm{~K}$ in fly ashes and bottom ash were calculated using Eq. (4) [31].

$\mathrm{D}=0.462 \mathrm{C}_{\mathrm{Ra}}+0.604 \mathrm{C}_{\mathrm{Th}}+0.0417 \mathrm{C}_{\mathrm{K}}$

where $0462,0.604$ and 0.0417 are conversion factors for ${ }^{226} \mathrm{Ra}$, ${ }^{232} \mathrm{Th}$ and ${ }^{40} \mathrm{~K}$ in $\left(\mathrm{nGy} \mathrm{h}^{-1}\right) /\left(\mathrm{Bq} \mathrm{kg}^{-1}\right)$, respectively.

The annual outdoors effective dose rate, EDR, was calculated by Eq. (5) using a conversion coefficient of $0.7 \mathrm{~Sv}$ $\mathrm{G}^{-1} \mathrm{y}^{-1}$ to convert the absorbed dose in the air into the effective dose in the human body. This calculation takes into account that the people spend about $20 \%$ of the time outdoors (outdoor occupancy factor $\mathrm{p}$ is 0.2 ) and $\mathrm{t}$ is $8.760 \mathrm{~h}$ annual exposure time.

$\operatorname{EDR}\left(\mathrm{mSv} \mathrm{y}^{-1}\right)=D\left(\mathrm{nGy} \mathrm{h}^{-1}\right) \times \mathrm{t} \times \mathrm{p}\left(\mathrm{h} \mathrm{y}^{-1}\right) 0.7\left(\mathrm{~Sv} \mathrm{G}^{-1} \mathrm{y}^{-1}\right) 10^{-6}$

\section{Results and discussion}

\section{Physical characteristics of ashes}

The particle size distribution curves of ashes are present in Figs. 1, 2 and 3. The mean diameter, $\mathrm{D}_{50}$, for FA and LFA is $30.57 \mu \mathrm{m}$ and $42 \mu \mathrm{m}$, respectively and $120 \mu \mathrm{m}$ for BA (Table 1). BA contains higher amount of large particles in comparison to FA and LFA, as the curve is moved to the right side. The particle size distribution for fly ash samples is broader than for bottom ash. Namely, particles in the range of 50 to $200 \mu \mathrm{m}$ in diameter are accounted for the most of the sample, while in FA and LFA most particles are in the range 10 and $110 \mu \mathrm{m}$. It is evident that all ashes have unimodal particle size distribution.

The obtained data for specific surface area, moisture content, particle density and bulk density, presented in Table 1 shows that a significantly higher specific surface area has bottom ash $\left(40.25 \mathrm{~m}^{2} \mathrm{~g}^{-1}\right)$ due to the presence of unburned coal particles. Moisture content is expected to be higher in the LFA and BA due to the weathering of landfilled fly ash and the production process of bottom ash. Particle density and bulk density is the highest for LFA, while is the lowest for BA. Bottom ash is known to have low particle density and low bulk density and is therefore commonly used as a lightweight aggregate or light fill material [1-3]. 
Fig. 1 Particle size distribution of FA

Fig. 2 Particle size distribution of LFA

The morphologies of fly ashes FA and LFA are presented in Fig. 4. It is evident heterogenic distribution of particles, the presence of typical fly ash cenospheres with dimensions from 2 to $20 \mu \mathrm{m}$, particles with a smooth surface, but irregular geometry and coarse particles mainly composed of unburned carbon. Much coarser particles with irregular geometry and sharp edges are observed in bottom ash (Fig. 4c). Bigger porous particles originate from coal are more widespread in the bottom ash, confirmed by the chemical composition (Table 2). Similar morphology observation for both ashes has also been noticed in [2].

\section{Chemical and mineralogical composition of ashes}

The chemical composition of ashes is influenced mainly by the type of coal being burned and used combustion conditions [6]. The chemical compositions of investigated fly ashes and bottom ash are presented in Table 2. It is obvious that chemical composition of bottom ash is similar to the fly ash, but as expected contain higher content of unburned carbon. The present metal oxides are in the order: $\mathrm{SiO}_{2}>\mathrm{Al}_{2} \mathrm{O}_{3}>\mathrm{Fe}_{2} \mathrm{O}_{3}>\mathrm{CaO}>\mathrm{MgO}>\mathrm{K}_{2} \mathrm{O}>\mathrm{Na}_{2} \mathrm{O}>\mathrm{TiO}_{2}$. The sum of $\mathrm{SiO}_{2}+\mathrm{Al}_{2} \mathrm{O}_{3}+\mathrm{Fe}_{2} \mathrm{O}_{3}$ in fly ashes is higher 
Fig. 3 Particle size distribution of BA

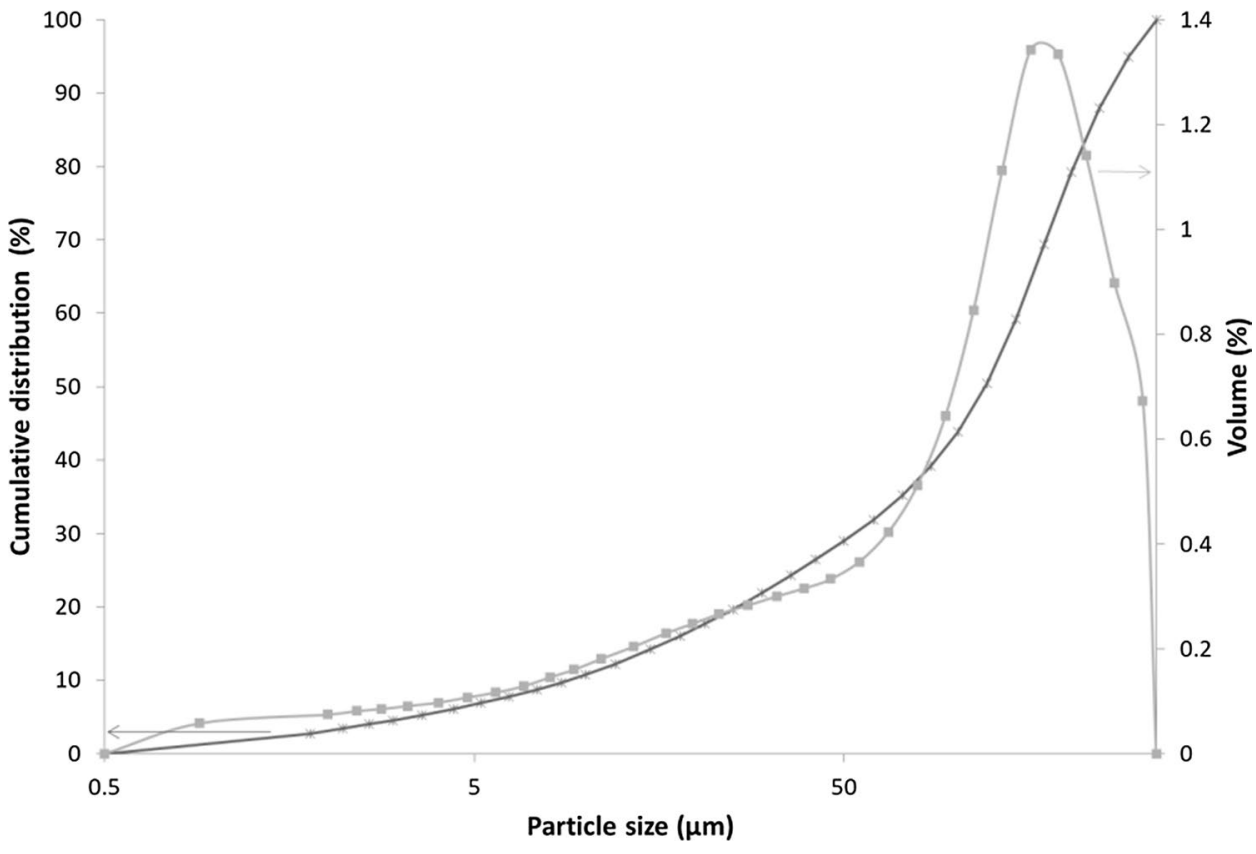

Table 1 Physical characteristics of the investigated coal ashes

\begin{tabular}{llll}
\hline Property & FA & LFA & BA \\
\hline Specific surface area, $\left(\mathrm{m}^{2} \mathrm{~g}^{-1}\right)$ & 5.97 & 22.71 & 40.25 \\
Moisture content, $(\mathrm{wt} . \%)$ & 1.36 & 4.42 & 4.46 \\
Particle density, $\left(\mathrm{g} \mathrm{cm}^{-3}\right)$ & 2.01 & 2.12 & 1.88 \\
Bulk density, $\left(\mathrm{kg} \mathrm{dm}^{-3}\right)$ & 573 & 684 & 582 \\
$\mathrm{D}_{50}(\mu \mathrm{m})$ & 30.57 & 42 & 120 \\
\hline
\end{tabular}

than $70 \mathrm{wt} . \%$ and $\mathrm{CaO}$ content is lower (less than $10 \mathrm{wt} . \%$ ) implies to fly ash $\mathrm{F}$ type i.e. siliceous ashes with pozzolanic properties [32, 33]. According to [34] FA belongs to type $\mathrm{V}$ (siliceous fly ash). The $\mathrm{SiO}_{2} / \mathrm{Al}_{2} \mathrm{O}_{3}$ ratio predicts the potential reactivity of fly ash. It is 2.31 and 2.18 for FA and LFA, respectively i.e. in range of reported in [6].

Reactive $\mathrm{SiO}_{2}$ in FA is 37.19 wt.\%, which is in accordance to the one of the criteria FA to be used as SCM's (supplementary cementitious materials) in cement production. Reactive $\mathrm{SiO}_{2}$ content shall not be less than 25 wt.\% [34]. In cement production FA can be used as raw material for clinker production or as pozzolanic additive in blended cements. The content of FA has to be optimized due to the fact that FA has early low reactivity that influence on decrease of early strength. When FA is used as additive to Portland cement, particularly F type of fly ash, there are many positive effects on the resulting concrete, such as: lower water demand for similar workability when OPC is used; decrease of ratio water-cement and capillary porosity; enhance concrete workability and reduce bleeding [6]. Due to the similar chemical (composed mainly of $\mathrm{SiO}_{2}, \mathrm{Al}_{2} \mathrm{O}_{3}$, $\mathrm{Fe}_{2} \mathrm{O}_{3}$ and $\mathrm{CaO}$ ) FA and $\mathrm{BA}$ can be used as replacement of clay in the brick production. The coarse particles influence on the plasticity index of clay and it can be used for decreasing of shrinkage in plastic clay.

An important parameter relating to the unburned carbon content is LOI (loss of ignition). As can be seen from Table 2, the highest value of LOI has BA (23.49 wt.\%). According to [33] the fresh FA (LOI $-2.43 \%$ ) belongs to group A $(\mathrm{LOI}<5)$ while the higher content in the landfilled fly ash (LFA) is associated with the type of the used coal and the combustion condition in the past. As for the bottom ash (BA), the large percentage of loss of ignition may be an advantage over some applications that require a high coal content and thus a loss of ignition. Authors [6] described possibility of usage of ashes with higher content of LOI as low-cost adsorbent for gas and water treatment, particularly as adsorbent of sulphur compound, NOx adsorbent, removal of mercury, adsorbent of organic compounds or removal of metals from waste water.

Trace/Heavy Elements, Rear Earth Elements (REE) and other main elements are presented in Tables 2, 3, 4 and 5.

The elements of greatest concern, are $\mathrm{As}, \mathrm{Cd}, \mathrm{Hg}, \mathrm{Pb}, \mathrm{Se}$ as well as $\mathrm{Zn}$, due to their potentially detrimental impact on human health and the environment. From the data presented in Table 3 especially the quantity of $\mathrm{As}, \mathrm{Cd}, \mathrm{Co}, \mathrm{Ch}, \mathrm{Cu}$, $\mathrm{Ni}$ and $\mathrm{V}$ are much lower than reported in [35]. Also, it is evident (Tables 2, 3, 4 and 5) that the quantity of some of the trace elements in fly ash is much higher than bottom ash which corresponds to the ratio between bottom ash and fly ash in pulverized coal combustion plants. The concentration of trace elements in the ashes depends on several factors including the type of coal feed, coal source, the occurrence of significant elements and their association with the organic 
Fig. 4 SEM/BSE microphotographs of the a FA, b LFA, c BA

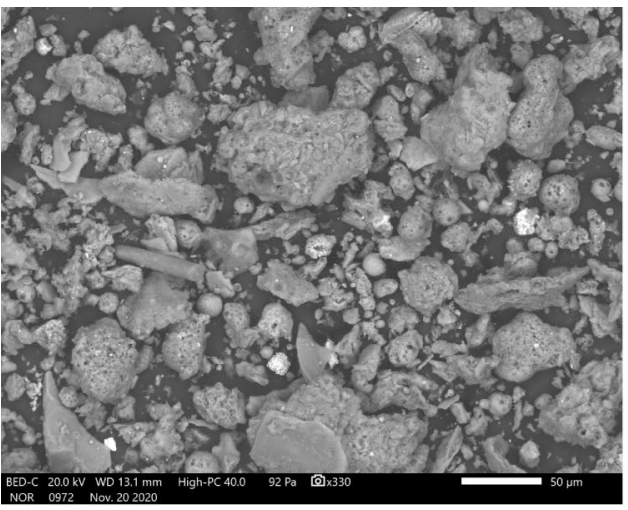

(a)

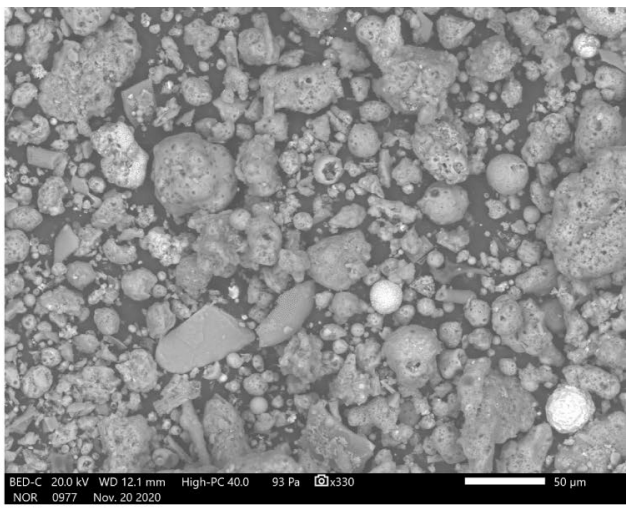

(b)

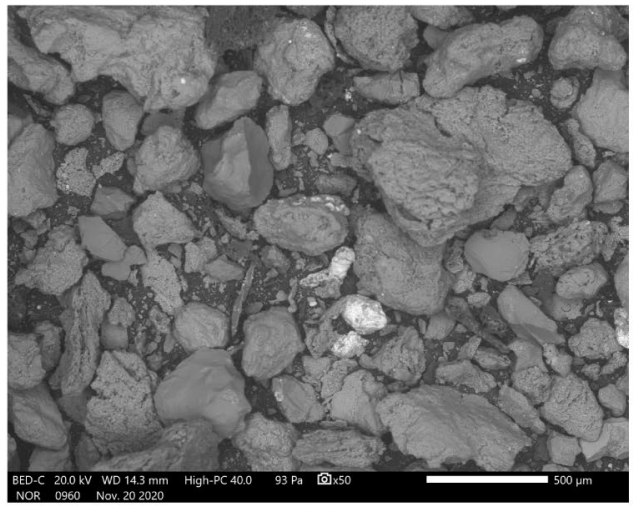

(c)

Table 2 Chemical composition of the investigated coal ashes

\begin{tabular}{|c|c|c|c|c|c|c|c|c|c|c|c|c|c|}
\hline \multirow[t]{2}{*}{ Ash } & \multicolumn{12}{|c|}{ Chemical composition, wt. $\%$} & \multirow[t]{2}{*}{$\sum$} \\
\hline & LOI & $\mathrm{SiO}_{2}$ & Reac $\mathrm{SiO}_{2}$ & $\mathrm{Al}_{2} \mathrm{O}_{3}$ & $\mathrm{Fe}_{2} \mathrm{O}_{3}$ & $\mathrm{CaO}$ & $\mathrm{MgO}$ & $\mathrm{SO}_{3}$ & $\mathrm{~K}_{2} \mathrm{O}$ & $\mathrm{Na}_{2} \mathrm{O}$ & $\mathrm{P}_{2} \mathrm{O}_{5}$ & $\mathrm{TiO}_{2}$ & \\
\hline FA & 2.42 & 53.49 & 37.19 & 23.16 & 7.73 & 3.31 & 2.18 & 0.72 & 3.13 & 0.98 & 0.15 & 0.92 & 98.19 \\
\hline LFA & 9.74 & 49.25 & - & 22.61 & 7.23 & 5.13 & 2.13 & 0.29 & 1.91 & 0.39 & 0.17 & 0.74 & 99.58 \\
\hline BA & 23.49 & 48.47 & - & 15.67 & 5.01 & 1.77 & 1.22 & 0.19 & 2.14 & 0.59 & 0.09 & 0.52 & 99.16 \\
\hline
\end{tabular}

and inorganic components of the coal, combustion conditions, volatilization-condensation mechanisms and the particle size of the ash. The fine ash particles, which have relatively larger surface areas, are in general enriched in trace elements [35]. Generally, most trace elements in coal ashes do not pose a threat when it is used for construction purposes. A previous study [36] confirms that leaching of trace elements from fly ash concrete was in the frame of the legal specifications. Concrete containing fly ash samples poses similar or higher trace element concentrations compared to Portland cement concrete. However, hazardous trace elements in ashes might pose environmental and public health risk. It is highly important to analyze the occurrence, distribution and mobility of trace elements for better management and possible remediation strategy. Liu et al. [37] found that low- mobility of trace elements (including $\mathrm{Cr}, \mathrm{Co}, \mathrm{Cu}, \mathrm{Ni}$,
$\mathrm{Zn}, \mathrm{Cd}$ and $\mathrm{Pb}$ ) in class $\mathrm{F}$ fly ash which might be a result of particle encapsulation by glass phase.

Besides certain heavy elements, coal fly ash also contains valuable rare earth elements (REE). Fresh fly ash contained $<380.8 \mathrm{ppm}$ of REEs with a noteworthy ratio of heavy (Y, Eu, Gd, Tb, Dy, Ho, Er, Tm, Yb) to light (Sc, La, $\mathrm{Ce}, \mathrm{Pr}, \mathrm{Sm})$ rare earth element $(<0.23)$. Taking into account the fact that ashes have no mining costs, the recovery of REEs could be potentially viable from the economic and environmental point of view.

Table 6 shows the content of amorphous and crystalline phases present in coal ashes. According to Blissett and Rowson [38] the mineralogy classification system divided four phase-mineral fly ash types namely Pozzolanic (P), Inert (I), Active (A) and Mixed (M): this is based on the distinct behavior of (1) glass; (2) quartz and mullite; and (3) the sum of any other mineral-bearing phases such as 
Table 3 Trace/Heavy elements in the investigated coal ashes

\begin{tabular}{|c|c|c|c|}
\hline \multirow{2}{*}{$\begin{array}{l}\text { Parameter } \\
\text { Trace/Heavy ele- } \\
\text { ments }\end{array}$} & \multicolumn{3}{|c|}{ Results (mg kg $\left.{ }^{-1}\right)$} \\
\hline & FA & LFA & $\mathrm{BA}$ \\
\hline $\mathrm{Pb}$ & $47 \pm 9.4$ & $23 \pm 4.6$ & $28 \pm 5.6$ \\
\hline As & $50 \pm 15$ & $148 \pm 44.4$ & $<20$ \\
\hline $\mathrm{Zn}$ & $150 \pm 15$ & $79 \pm 7.9$ & $75 \pm 7.5$ \\
\hline Co & $19 \pm 5.7$ & $12 \pm 3.6$ & $6,6 \pm 1.98$ \\
\hline $\mathrm{Cd}$ & $<2$ & $<2$ & $<2$ \\
\hline $\mathrm{Cr}$ & $103 \pm 10.3$ & $82 \pm 8.2$ & $76 \pm 7.6$ \\
\hline $\mathrm{Ni}$ & $66 \pm 13.2$ & $58 \pm 11.6$ & $39 \pm 7.8$ \\
\hline $\mathrm{Sb}$ & $<10$ & $<10$ & $<10$ \\
\hline Mn & $1333 \pm 266.6$ & $875 \pm 175$ & $1667 \pm 333.4$ \\
\hline $\mathrm{Cu}$ & $130 \pm 39$ & $87 \pm 26.1$ & $34 \pm 10.2$ \\
\hline $\mathrm{Ag}$ & $<10$ & $<10$ & $<10$ \\
\hline $\mathrm{Ba}$ & $692 \pm 69.2$ & $506 \pm 50.6$ & $406 \pm 40.6$ \\
\hline $\mathrm{Sr}$ & $300 \pm 30$ & $273 \pm 27.3$ & $149 \pm 14.9$ \\
\hline $\mathrm{Ga}$ & $43 \pm 21.5$ & $39 \pm 19.5$ & $24 \pm 12$ \\
\hline $\mathrm{Nb}$ & $24 \pm 2.4$ & $22 \pm 2.2$ & $14 \pm 1.4$ \\
\hline $\mathrm{Ta}$ & $<20$ & $<20$ & $<20$ \\
\hline Th & $34 \pm 13.6$ & $27 \pm 10.8$ & $18 \pm 7.2$ \\
\hline $\mathrm{U}$ & $<30$ & $<30$ & $<30$ \\
\hline V & $138 \pm 27.6$ & $115 \pm 23$ & $60 \pm 12$ \\
\hline $\mathrm{Zr}$ & $125 \pm 12.5$ & $87 \pm 8.7$ & $50 \pm 5$ \\
\hline $\mathrm{Hg}$ & $0.0097 \pm 0.00$ & $0.0364 \pm 0.0083$ & $0.0102 \pm 0.0006$ \\
\hline
\end{tabular}

Table 4 REE elements in the investigated coal ashes

\begin{tabular}{llll}
\hline Parameter & \multicolumn{2}{l}{ Results $\left(\mathrm{mg} \mathrm{kg}^{-1}\right)$} \\
\cline { 2 - 4 } REE elements & FA & LFA & BA \\
\hline $\mathrm{Ce}$ & $141 \pm 14.1$ & $130 \pm 13$ & $75 \pm 7.5$ \\
$\mathrm{Dy}$ & $7.1 \pm 1.42$ & $7.5 \pm 1.5$ & $<5$ \\
$\mathrm{Er}$ & $<5$ & $6,6 \pm 2.64$ & $<5$ \\
$\mathrm{Eu}$ & $<3$ & $<3$ & $<3$ \\
$\mathrm{Gd}$ & $<10$ & $11 \pm 2.2$ & $<10$ \\
$\mathrm{Ho}$ & $<5$ & $<5$ & $<5$ \\
$\mathrm{La}$ & $71 \pm 7.1$ & $51 \pm 5.1$ & $40 \pm 4$ \\
$\mathrm{Nd}$ & $57 \pm 11.4$ & $49 \pm 9.8$ & $28 \pm 5.6$ \\
$\mathrm{Pr}$ & $<10$ & $<10$ & $<10$ \\
$\mathrm{Sm}$ & $11 \pm 2.2$ & $12 \pm 2.4$ & $6.3 \pm 1.26$ \\
$\mathrm{Sc}$ & $13 \pm 2.6$ & $14 \pm 2.8$ & $7.0 \pm 1.4$ \\
$\mathrm{~Tb}$ & $<5$ & $<5$ & $<5$ \\
$\mathrm{Tm}$ & $<5$ & $<5$ & $<5$ \\
$\mathrm{Yb}$ & $3.7 \pm 0.74$ & $4.7 \pm 0.94$ & $1.7 \pm 0.34$ \\
$\mathrm{Y}$ & $34 \pm 6.8$ & $35 \pm 7$ & $16 \pm 3.2$ \\
\hline
\end{tabular}

**Lutetium was used as an internal standard, so it was not measured in the sample
Table $5 \mathrm{Be}$ as another main element in the investigated coal ashes

\begin{tabular}{llll}
\hline Parameter & \multicolumn{4}{l}{ Results $\left(\mathrm{mg} \mathrm{kg}^{-1}\right)$} \\
\cline { 2 - 4 } Other main element & FA & LFA & BA \\
\hline $\mathrm{Be}$ & $7.4 \pm 0.74$ & $5.2 \pm 0.52$ & $4.1 \pm 0.41$ \\
\hline
\end{tabular}

$\mathrm{Fe}-\mathrm{Ca}-\mathrm{Mg}-\mathrm{K}-\mathrm{Na}-\mathrm{Ti}-\mathrm{Mn}$ oxides, hydroxides, sulfates, carbonates and silicates. Classifying fly ash in this way should help to simplify the choice of application for each unique fly ash composition.

\section{Radiological characterization}

\section{Gamma-ray spectrometry}

Table 7 presents the activity concentrations of ${ }^{226} \mathrm{Ra},{ }^{232} \mathrm{Th}$ and ${ }^{40} \mathrm{~K}$ and I-index of examined fly ashes and bottom ash and the some typical values given for comparison.

Activity concentrations for ${ }^{226} \mathrm{Ra}$ in the examinated fly ashes and bottom ash are lower than EU typical and maximal values [39]. Also, ${ }^{226}$ Ra activity concentrations are lower than $207 \mathrm{~Bq} \mathrm{~kg}^{-1}$ reported as an average activity concentration of this radionuclide for EU fly ashes [40]. The results are comparable with the ones reporeted in [41, 42]. It is noticable that FA has significantly higher content of all measured radionuclides. The activity concentrations for ${ }^{232} \mathrm{Th}$ are higher for both fly ashes than the reported values [43], but only FA has a higher ${ }^{232} \mathrm{Th}$ activity concentration in relation to the value reported in $[39,42]$. Regarding ${ }^{40} \mathrm{~K}$ only FA has a higher content than the values reported in $[39,40]$. As discussed in [43], the activity concentration is correlated to the finnes of the particles present in the material. The finner the particles, the higher the activity concentration, which can be clearly seen from the obtained results.

Regarding the I-index, only FA has value higher than 1 [44], but for the raw materials, it is only used as a screening tool. Fly ash can be used as a raw material in final building materials (like clinker, cement, concrete, brick, glass-ceramics, etc.) in certain mass portion (usually much lower than $100 \%)$. For example, in portland fly ash cement, a maximum of $35 \mathrm{wt} . \%$ of fly ash can be used [34]. Moreover, large number of samples analyzed in $[43,45,46]$ showed that the final product (Portland cement and other building materials) had I lower than unity in all investigated samples which used FA as a component. Therefore the contribution of radionuclide content originating from the fly ash in these products is lower and the overall I-index for such products would be lower than 1 . 
Table 6 Content of amorphous and crystalline phases in coal ashes (wt. \%)
Table 7 Activity concentrations $\left(\mathrm{Bq} \mathrm{kg}^{-1}\right)$ and I-index of ashes

\begin{tabular}{lcccllll}
\hline Sample & Hematite & Illite/muscovite & Quartz & Plagioclase & K-feldspar & Dolomite & Amorphous \\
\hline FA & 0.5 & 9.8 & 8.7 & 13.7 & - & 0.1 & 67.2 \\
LFA & 1.1 & - & 6.2 & 16.1 & - & 0.1 & 76.5 \\
BA & - & 10.2 & 17.9 & 13.2 & 8.9 & 0.1 & 49.7 \\
\hline
\end{tabular}

\begin{tabular}{|c|c|c|c|c|}
\hline \multirow[t]{2}{*}{ Sample and literature referent value } & \multicolumn{3}{|c|}{ Activity concentrations $\left(\mathrm{Bq} \mathrm{kg}^{-1}\right)$} & \multirow[t]{2}{*}{ I- index } \\
\hline & ${ }^{226} \mathrm{Ra}$ & ${ }^{232} \mathrm{Th}$ & ${ }^{40} \mathrm{~K}$ & \\
\hline FA & $143 \pm 7$ & $116 \pm 9$ & $719 \pm 50$ & 1.30 \\
\hline LFA & $83.5 \pm 4$ & $88 \pm 6$ & $383 \pm 25$ & 0.85 \\
\hline BA & $69.5 \pm 4$ & $63 \pm 6$ & $457 \pm 35$ & 0.7 \\
\hline Typical activity concentration [39] & 180 & 100 & 650 & \\
\hline Fly ash [40] & 207 & 80 & 564 & \\
\hline Maximal activity concentration [39] & 1100 & 300 & 1500 & \\
\hline
\end{tabular}

Table 8 Calculated radium equivalent activity $\left(\mathrm{Ra}_{\mathrm{eq}}\right)$, external hazards index $\left(\mathrm{H}_{\mathrm{ex}}\right)$, external absorbed dose rate (D) and annual effective dose rate $(\mathrm{EDR})$ for the ashes

\begin{tabular}{lllll}
\hline Sample & $\mathrm{Ra}_{\mathrm{eq}}\left(\mathrm{Bq} \mathrm{kg}^{-1}\right)$ & $\mathrm{H}_{\mathrm{ex}}\left(\mathrm{Bq} \mathrm{kg}^{-1}\right)$ & $\mathrm{D}\left(\mathrm{nGy} \mathrm{h}^{-1}\right)$ & $\begin{array}{l}\mathrm{EDR}(\mathrm{mSv} \\
\left.\mathrm{y}^{-1}\right)\end{array}$ \\
\hline FA & 364.24 & 1.00 & 166.11 & 0.20 \\
LFA & 238.83 & 0.66 & 107.70 & 0.13 \\
BA & 194.78 & 0.54 & 89.22 & 0.11 \\
\hline
\end{tabular}

\section{Dose assessment $\&$ radium equivalent activity $\&$ The external hazard index}

Radium equivalent activity $\left(\mathrm{Ra}_{\mathrm{eq}}\right)$, external hazards index $\left(\mathrm{H}_{\mathrm{ex}}\right)$, the external absorbed dose rate (D) and annual effective dose rate (EDR) were calculated in order to estimate a possible health effect due to the exposure of public to natural radionuclides present in the ashes, Table 8 .

$\mathrm{Ra}_{\mathrm{eq}}$ for all examined ashes is lower than $370 \mathrm{~Bq} \mathrm{~kg}^{-1}$ which proves that the estimated hazard (gamma dose) associated with ashes containing ${ }^{226} \mathrm{Ra},{ }^{232} \mathrm{Th}$ and ${ }^{40} \mathrm{~K}$ is under the limit of $1 \mathrm{mSv}^{-1}[31]$.

Another radiological criteria to estimate the suitability of materials, from the radiological point of view, is the external hazard index, $\mathrm{H}_{\mathrm{ex}}$, which value has to be $<1$. The $\mathrm{H}_{\mathrm{ex}}$ values for LFA and BA are lower than the limited one, but for FA the value is on the border of the prescribed limit, which is to be expected considering the relatively high value of $\mathrm{Ra}_{\mathrm{eq}}$.

The values for external absorbed dose rate, D, for examined ashes are higher than the estimated value of $60 \mathrm{nGy}$ $\mathrm{h}^{-1}$ for the population-weighted average in the outdoor air from terrestrial gamma radiation [44]. Sanjuán [47] reported the value of $141 \mathrm{nGy} \mathrm{h}^{-1}$ for fly ash. It was used as a raw material in the CEM IV cement where the external absorbed dose rate was under the prescribed limits $\left(39 \mathrm{nGy} \mathrm{h}^{-1}\right)$ due to the use of a certain portion of fly ash in the final cement product. In [44] the reported external absorbed dose in the samples of Portland fly-ash cement and Portland-composite cement with FA ranged from 40.6 to $94.7 \mathrm{nGy} \mathrm{h}^{-1}$. In pozzolanic Portland cement with siliceous FA, this value ranged from 66.3 to $176.6 \mathrm{nGy} \mathrm{h}^{-1}$, while in the case of natural pozzolan cements, the external absorbed dose ranged from 57.3 to $101.9 \mathrm{nGy} \mathrm{h}^{-1}$. According to this data, it is not expected that the addition of FA as a constituent of Portland cement would have a significant impact on the external absorbed dose originating from the final product.

The annual effective dose rate for all ashes is $\leq 0.2 \mathrm{mSv} \mathrm{y}^{-1}$. The values are below the average global annual indoor absorbed dose rate in the air $\left(0.41 \mathrm{mSv} \mathrm{y}^{-1}\right)$ from terrestrial sources of the radioactivity [48] and the effective dose rate threshold level of $1 \mathrm{mSv} \mathrm{y}^{-1}$ given for the population by the European Basic Safety Standard [20]. This conclusion is in agreement with the conclusion regarding annual effective dose rate given in [44].

Higher values of $\mathrm{Ra}_{\mathrm{eq}}, \mathrm{H}_{\mathrm{ex}}$, D and EDR for FA are to be expected as all of these values are directly dependent on the activity concentration of ${ }^{226} \mathrm{Ra},{ }^{232} \mathrm{Th}$ and ${ }^{40} \mathrm{~K}$. Again, as it was shown in [43], the activity concentration of naturally occurring radionuclides is correlated to the grain size of the material and since the fly ash has the smallest grain size, it is expected to have the highest content of radionuclides and therefore the largest values of $\mathrm{Ra}_{\mathrm{eq}}, \mathrm{H}_{\mathrm{ex}}, \mathrm{D}$ and EDR.

\section{Conclusions}

In this study, fly ash (fresh and landfilled) and bottom ash from thermal power plant REK Bitola, Republic of North Macedonia have been characterized from physical, chemical 
and radiological aspect. Based on the presented results and reviewed literature, the summary of the paper is as follows:

- The physical characteristics (specific surface area, moisture content, particle density and bulk density) of landfilled fly ash (LFA) is generally higher in comparison to the fly ash obtained from electro filter (FA). Bottom ash (BA) has higher specific surface area $\left(40.25 \mathrm{~m}^{2} / \mathrm{g}\right)$ and lower particle density $\left(1.88 \mathrm{~g} / \mathrm{cm}^{3}\right)$ in relation to the both fly ashes, higher moisture content $(4.46 \%)$ in relation to fly ash (1.3\%) and possess coarser particles $\left(\mathrm{D}_{50}=120 \mu \mathrm{m}\right)$ with irregular geometry in comparison to the both ashes.

- Relating to the chemical composition, fly ash belongs to siliceous ash with pozzolanic properties. The biggest content of unburned coal was detected in bottom ash resulting in high amount of LOI (23.49 wt. \%). Relating to the trace/heavy elements, FA shows the highest values for most of them. The content of the most rare earth elements was lower in BA. Both fly ashes are characterized with high content of amorphous phase (more than $65 \%$ ) and quartz and plagioclase are the dominant minerals in all investigated ashes.

- Based on the calculated doses and having in mind that the ash is used in certain portion in final product, the low impact from a radiological viewpoint can be concluded for all three examined ashes.

The exanimated ashes in this paper have the potential for utilization as secondary raw material in construction sector (cement, concrete, bricks, tiles, glass-ceramics, geothermal purposes....), but also the possibilities for their green transformation (carbon nanotubes, geopolymers, absorbents, rare earth elements, zeolites...) are foreseen. Anyway, more particular investigations have to be performed for utilizing fly ashes and bottom ash as secondary raw materials taking into account the purpose and the type of the final products.

Acknowledgements The study has received funding from the European Institute of Innovation and Technology (EIT), a body of the European Union, under the Horizon 2020, the EU Framework Programme for Research and Innovation (RIS-ALiCE, project no. 18258). The authors would like to thank Bence Kószó from Bay Zoltán Nonprofit Ltd. for Applied Research, Division for Biotechnology (BAY-BIO) H-6726 Szeged, Hungary for the realized ICP-OES analyses.

Open Access This article is licensed under a Creative Commons Attribution 4.0 International License, which permits use, sharing, adaptation, distribution and reproduction in any medium or format, as long as you give appropriate credit to the original author(s) and the source, provide a link to the Creative Commons licence, and indicate if changes were made. The images or other third party material in this article are included in the article's Creative Commons licence, unless indicated otherwise in a credit line to the material. If material is not included in the article's Creative Commons licence and your intended use is not permitted by statutory regulation or exceeds the permitted use, you will need to obtain permission directly from the copyright holder. To view a copy of this licence, visit http://creativecommons.org/licenses/by/4.0/.

\section{References}

1. Ramzi NIR, Shahiron S, Maarof MZ, Ali N (2016) Physical and chemical properties of coal bottom ash (CBA) from Tanjung Bin Power Plant. IOP Conf Ser: Mater Sci Eng: 012056

2. Reddy CS, Mohanty S, Shaik R (2018) Physical, chemical and geotechnical characterization of fly ash, bottom ash and municipal solid waste from Telangana State in India. Geo-Engineering 9:23

3. Kumar D, Kumar N, Gupta A (2014) Geotechnical properties of fly ash and bottom ash mixtures in different proportions. Int J Sci Res 3(9):1487-1494

4. Komljenović M, Petrašinović-Stojkanović L, Jovanović BZ, N, (2009) Fly ash as the potential raw mixture component for Portland cement clinker synthesis. J Therm Anal Calorim 96:363-368

5. Kramar S, Žibret L, Fidanchevska E, Jovanov V, Angjusheva B, Ducman V (2019) Use of fly ash and phosphogypsum for the synthesis of belite-sulfoaluminate clinker, Mater de Construccion 69 (333): e176

6. Argiz C, Menéndez E, Moragues A, Sanjuán MA (2015) Fly ash characteristics of Spanish coal-fired power plants. AFINIDAD LXXI I:572

7. Nanni A, Ludwig D, Shoenberger J (1996) Roller compacted concrete for highway pavements. Concr Int 18(5):33-38

8. Lingling X, Wei G, Tao W, Nanru Y (2005) Study on fired bricks with replacing clay by fly ash in high volume ratio. Constr Build Mater 19:243-247

9. Zeng L, Sun HJ, Peng TJ, Zheng WM (2019) The sintering kinetics and properties of sintered glass-ceramics from coal fly ash of different particle size. Results in Phys. 15:102774

10. Mohapatra R, Rao JR (2001) Some aspects of characterization, utilization and environmental effects of fly ash. J Chem Technol Biotechnol 76:9-26

11. Boycheva S, Zgureva D, Lazarova H, Popova M (2021) Comparative study of carbon capture onto coal fly ash zeolites Na-X and Na-Ca-X. Chemosphere 27: 129505

12. Gollakota ARK, Volli V, Shu SM (2019) Progressive utilization prospects of coal fly ash: A review. Sci Total Environ 672:951-989

13. Ullah A, Kassim A, Matusin S, Rashid ASA, Yunus NZM, Abuelgasim R (2020) Evaluation of coal bottom ashproperties and its applicability as engineering material. IConCEES 2019 498: 012044

14. Dolenec S, Šter K, Borštnar M, Nagode K, Ipavec A, Žibret L (2020) Effect of the cooling regime on the minerology and reactivity of belite-sulfoaluminate clinkers. Minerals 10:910

15. Bajare D, Bumanis G, Upeniece L (2013) Coal combustion bottom ash as microfiller with pozzolanic properties for traditional concrete. Procedia Eng 57:149-158

16. Argiz C, Sanjuán MA, Menéndez E (2017) Coal bottom ash for Portland cement production. Advances in Mat Science \& Eng. 6068286

17. Vu DH, Wang KS, Chen JH, Nam BX, Bac BH (2012) Glassceramic from mixtures of bottom ash and fly ash. Waste Manage 32:2306-2314

18. Angjusheva B, Fidancevska E, Ducman V (2016) Influence of the main process parameters on the physical and mechanical properties of the bottom ash ceramics. Qual Life 73-4:59-65

19. http://www.ecoba.com/evjm,media/downloads/CPI_report_engli sh_0406_en.pdf, Accessed 15 Sep 2020 
20. Directive 2013/59/EUROATOM 5-December 2013, Official European Union 17/01/2014, 2013

21. Žibret G, Teren K, Žibret L, Šter K, Dolenec S (2021) Building of the Al-containing secondary raw materials registry for the production of low $\mathrm{CO}_{2}$ mineral binders in South-Eastern European Region. Sustainability 13(3):1535

22. https://www.alice-registry.eu/

23. ELEM -Macedonian Power Plants, http://www.elem.com.mk/ index.php, Accessed 05 June 2019

24. Popovska N, Masters Thesis, University Goce Delcev Shtip, RN Macedonia (2012) http//www.eprints.ugd.edu.mk/. Accessed 02 May 15

25. EN933-1:2012 Tests for geometrical properties of aggregates. Determination of particle size distribution. Sieving method

26. EN1097-7:2008 Tests for mechanical and physical properties of aggregates. Determination of the particle density of filler. Pycnometer method

27. JUS B.C8.023:1982 Methods of testing the physical properties of cement

28. EN196-2 :2013 Method of testing cement - Part 2: Chemical analysis of cement

29. MSZ525-17:2013 Chemical analysis of cement. Part 17: Determination of total chrome content as $\mathrm{Cr}_{2} \mathrm{O}_{3}$

30. Nenadović S, Fereone C, Nenadović M, Cioffi R, Mirković M, Vukanac I, Lj K (2020) Chemical, physical and radiological evaluation of raw materials and geopolymers for building applications. J Radioanal Nucl Chem 325:435-445

31. UNSCEAR (2000) Sources and effects of ionizing radiationUnited Nations Scientific Committe on the effects of Atomic Radiation, UNSCEAR 2000 Report to the General Assembly with Scientific Annexes, United Nations New York

32. ASTM C618-05, Standard specification for coal fly ash and raw or calcined natural pozzolan for use in concrete, Annual book of ASTM standards, 2005, concrete and aggregates, 04.02:1-4

33. EN 450-1:2012 Fly ash for concrete - Part 1: Definition, specifications and conformity criteria

34. EN 197-1:2011 Cement - Part 1: Composition, specifications and conformity criteria for common cements

35. Nalbandian H (2012) Trace elements emissions from coal. IEA Clean Coal Centre. ISBN 978-92-9029-523-5

36. Smith I M (2005) Land uses of coal fly ash - benefits and barriers. CCC/96, London, UK, IEA Clean Coal Centre, $30 \mathrm{pp}$

37. Liu P, Wang Q, Jung H, Tang Y (2020) Specification, distribution and mobility of hazardous trace elements in coal fly ash: insights from $\mathrm{Cr}$, Ni and Cu. Energ Fuel 34(11):14333-14343
38. Blissett RS, Rowson NA (2012) A review of the multi-component utilisation of coal fly ash. Fuel 97:1-23

39. EC (European Commission) (1999) Radiation protection 112. Radiological protection principles concerning the natural radioactivity of building materials. Directorate-General Environment, Nuclear Safety and Civil Protection

40. Nuccetelli C, Pontikes Y, Leonardi F, Trevisi R (2015) New perspectives and issues arising from the introduction of (NORM) residues in building materials: acritical assessment on the radiological behaviour. Constr Build Mater 82:323-331

41. Janković MM, Todorović DJ, Nikolić JD (2011) Analysis of natural radionucleides in coal, slag and ash in coal-fired power plants in Serbia. J Min Metall Sect B-Metall 47(2):149-155

42. Boukhair A, Belahbib L, Azkour K, Nebdi H, Benjelloun M, Nourreddine A (2016) Measurement of natural radioactivity and radon exhalation rate in coal ash samples from a thermal power plant. WJNST 6:153-160ó

43. Sanjuán MA, Suarez-Navarro JA, Argiz C, Estévez E (2021) Radiation dose calculation of fine and coarse coal fly ash used for building purposes. J Radioanal Nucl Chem 327:1045-1054

44. UNSCEAR (2000) Report of the United Nations Scientific Committee on the effect of atomic radiation to the general assembly of the United Nations. Sources and effect of ionizing radiation. Anex B: exposures from natural radiation sources. New York: United Nations Sales Publication E.00.IX.3; 2000

45. Sanjuán MA, Suarez-Navarro JA, Argiz C, Mora P (2020) Assessment of natural radioactivity and radiation hazards owing to coal fly ash and natural pozzolan Portland cements. J Radioanal Nucl Chem 325:381-390

46. Chinchón-Payá S, Piedecausa B, Hurtado S, Sanjuán MA, Chinchón S (2011) Radiological impact of cement, concrete and admixtures in Spain. Radiat Meas 46:734-735

47. Sanjuán MA, Quintana B, Argiz C (2019) Coal bottom ash natural radioactivity in building materials. J Radioanal Nucl Chem 319:91-99

48. UNSCEAR (1988) Report, sources, effects and risks of ionic radiation. United Nation Scientific Committee on the Effects of Atomic Radiation. Report to the General Assembly with Annexes, United Nations New York

Publisher's Note Springer Nature remains neutral with regard to jurisdictional claims in published maps and institutional affiliations. 